\title{
DIFFERENT TYPES OF POTASSIUM TRANSPORT LINKED TO CARBACHOL AND $\gamma$-AMINOBUTYRIC ACID ACTIONS IN RAT SYMPATHETIC NEURONS
}

\author{
K. Ballanyi, P. Grafe*, M. M. Reddy and G. ten Bruggencate \\ Department of Physiology, University of Munich, Pettenkoferstr. 12, D-8000 München 2, F.R.G.
}

\begin{abstract}
Carbachol and $\gamma$-aminobutyric acid depolarize mammalian sympathetic neurons and increase the free extracellular $\mathrm{K}^{+}$-concentration. We have used double-barrelled ion-sensitive microelectrodes to determine changes of the membrane potential and of the free intracellular $\mathrm{Na}^{+}, \mathrm{K}^{+}-$and $\mathrm{Cl}$-concentrations $\left(\left[\mathrm{Na}^{\prime}\right]_{i},\left[\mathrm{~K}^{\prime}\right]_{j}\right.$ and $\left.[\mathrm{Cl}]_{i}\right)$ during neurotransmitter application. Experiments were performed on isolated, desheathed superior cervical ganglia of the rat, maintained in Krebs solution at $30^{\circ} \mathrm{C}$. Application of carbachol resulted in a membrane depolarization accompanied by an increase of $\left[\mathrm{Na}^{+}\right]_{i}$, a decrease of $\left[\mathrm{K}^{+}\right]_{i}$ and no change in $\left[\mathrm{Cl}^{-}\right]_{1}$. Application of $\gamma$-aminobutyric acid also induced a membrane depolarization which, however, was accompanied by a decrease of $\left[\mathrm{K}^{+}\right]_{\mathrm{i}}$ and $\left[\mathrm{Cl}^{-}\right]_{i}$, whereas $\left[\mathrm{Na}^{+}\right]_{i}$ remained constant. Blockade of the $\mathrm{Na}^{+} / \mathrm{K}^{+}$-pump by ouabain completely inhibited both the reuptake of $\mathrm{K}^{+}$and the extrusion of $\mathrm{Na}^{+}$after the action of carbachol, and also the post-carbachol undershoot of the free extracellular $\mathrm{K}^{+}$-concentration. On the other hand, in the presence of ouabain, no changes in the kinetics of the reuptake of $\mathbf{K}^{+}$released during the action of $\gamma$-aminobutyric acid could be observed. Furosemide, a blocker of $\mathrm{K}^{+} / \mathrm{Cl}^{-}$-cotransport, inhibited the reuptake of $\mathrm{Cl}^{-}$and $\mathrm{K}^{+}$after the action of $\gamma$-aminobutyric acid.

In summary, the data reveal that rat sympathetic neurons possess, in addition to the $\mathrm{Na}^{+} / \mathrm{K}^{+}$-pump, another transport system to regulate free intracellular $\mathrm{K}^{+}$-concentration. This system is possibly a $\mathrm{K}^{+} / \mathrm{Cl}^{-}$-cotransport.
\end{abstract}

Neuronal activity in the central and peripheral nervous system of mammals is accompanied by a release of $\mathrm{K}^{+}$into the extracellular space (for reviews see refs 24 and 28 ). In this context, it is generally assumed that the $\mathrm{Na}^{+} / \mathrm{K}^{+}$-pump, activated by an increase of intracellular $\mathrm{Na}^{+}$, is the mechanism responsible for the neuronal reuptake of $\mathrm{K}^{+}$. However, direct measurements of the free intracellular $\mathrm{Na}^{+}, \mathrm{K}^{+}$- and $\mathrm{Cl}^{-}$-concentrations $\left(\left[\mathrm{Na}^{+}\right]_{i},\left[\mathrm{~K}^{+}\right]_{\mathrm{i}}\right.$ and $\left.\left[\mathrm{Cl}^{-}\right]_{i}\right)$ in conjunction with the membrane potential of mammalian neurons during activation of the $\mathrm{Na}^{+} / \mathrm{K}^{+}$-pump have not yet been described. The first aim of the present study was to obtain these very basic data.

Furthermore, it is also known that $\mathrm{K}^{+}$can be released by neurons during events which are unlikely to be linked to an increase of $\left[\mathrm{Na}^{+}\right]_{i}$. Such an example is the increase of extracellular $\mathrm{K}^{+}$-concentration $\left(\left[\mathrm{K}^{+}\right]_{e}\right)$ accompanying the membrane depolarization produced by a $\gamma$-aminobutyric acid (GABA)-induced opening of $\mathrm{Cl}^{-}$channels. ${ }^{12,15,21,22,29}$ The second aim of the present study, therefore, was to investigate whether transport mechanisms in addition to the $\mathrm{Na}^{+} / \mathrm{K}^{+}$-pump might exist for the regulation of $\left[\mathrm{K}^{+}\right]_{\mathrm{i}}$ in the mammalian nervous system. In order to answer this question, intracellular recordings

Address for all correspondence: Dr. P. Grafe, Physiologisches Institut, Pettenkoferstr. 12, D-8000 München 2, F.R.G.

Abbreviations: GABA, $\gamma$-aminobutyric acid; $\left[\mathrm{K}^{+}\right]_{\mathrm{e}, \mathrm{i}}$, extracellular and intracellular concentrations, respectively, of free potassium ions; $\left[\mathrm{Na}^{+}\right]_{i},\left[\mathrm{Cl}^{-}\right]_{\mathrm{i}}$, intracellular concentrations of free sodium and chloride ions, respectively. with double-barrelled ion-sensitive microelectrodes were performed to study directly the effects of receptor agonists on free intracellular ion concentrations of neurons in rat superior cervical ganglia. In particular, effects of the acetylcholine-receptor agonist carbachol and of GABA on $\left[\mathrm{K}^{+}\right]_{\mathrm{i}},\left[\mathrm{Na}^{+}\right]_{\mathrm{i}}$ and $\left[\mathrm{Cl}^{-}\right]_{\mathrm{i}}$ have been tested. Specifically, mechanisms contributing to the neuronal reuptake of $\mathrm{K}^{+}$at the end of the neurotransmitter action were investigated using blockers of $\mathrm{K}^{+}$-transport systems (ouabain, furosemide). Parts of the results have been published in a preliminary form. ${ }^{4}$

\section{EXPERIMENTAL PROCEDURES}

\section{Preparation}

Experiments were performed on isolated superior cervical ganglia of rats. Following the dissection, the ganglia, including their pre- and postganglionic nerve trunks, were desheathed and placed in a recording chamber (vol $1.5 \mathrm{ml}$ ), which was continuously perfused with Krebs solution by means of a roller pump $(4 \mathrm{ml} / \mathrm{min})$. The $\mathrm{pH}$ of the Krebs solution was adjusted to 7.4 by gassing the fluid with a mixture of $95 \% \mathrm{O}_{2}$ and $5 \% \mathrm{CO}_{2}$. The $\mathrm{Krebs}$ solution contained (mM): $\mathrm{NaCl} 118 ; \mathrm{KCl} 4.8 ; \mathrm{NaHCO}_{3} 25 ; \mathrm{KH}_{2} \mathrm{PO}_{4} 1.2$; $\mathrm{MgSO}_{4} 1.2 ; \mathrm{CaCl}_{2} 2.5$ and D-glucose 10. The temperature of the superfusion fluid was maintained at $30^{\circ} \mathrm{C}$. Pre- and postganglionic nerve trunks were fixed with two suction electrodes, one for electrical stimulation and the other one for recording the postganglionic compound action potential. The cells were 
impaled by means of a piezo-step motor driven manipulator. Drugs were added to the superfusion solution (all drugs used in the present study were purchased from Sigma, Munich).

\section{Ion-sensitive microelectrodes}

The method used for the construction of the double-barrelled ion-sensitive microelectrodes was described elsewhere. ${ }^{19}$ In brief, theta-capillaries were pulled with a Brown-Flaming type microelectrode puller resulting in tip-diameters below $0.3 \mu \mathrm{m} .{ }^{8}$ For the determination of $\left[\mathrm{K}^{+}\right]_{\mathrm{i}}$ or $\left[\mathrm{K}^{+}\right]_{e}$, a Corning ion exchanger resin (477317) or a valinomycin-cocktail were filled into the ion-sensitive barrel; the reference barrel contained $1 \mathrm{M}$ magnesium-acetate $\mathrm{pH}$ adjusted to 7.4; resistance of ion-sensitive barrel: $10-50 \mathrm{G} \Omega$, of reference barrel $: \geq 100 \mathrm{M} \Omega$ ). All electrodes were calibrated before and after the experiments in solutions containing 3,12 and $60 \mathrm{mM} \mathrm{KCl}$ with a constant background of $150 \mathrm{mM} \mathrm{NaCl}$. The mean values for the slope for a tenfold change in $\mathrm{K}^{+}$ and the selectivity coefficient versus $\mathrm{Na}^{+}$at room temperature were $56.6 \pm 4.4 \mathrm{mV}$ and $0.019 \pm 0.008$ (mean $\pm \mathrm{SD}, n=21$ ), respectively. The method for the determination of $\left[\mathrm{K}^{+}\right]$, was described previously. ${ }^{19}$ For determination of $\left[\mathrm{Na}^{+}\right]$a $\mathrm{Na}^{+}$-sensitive neutral ligand (ETH 227) was used. The reference barrel, again, was filled with $1 \mathrm{M}$ magnesium-acetate. Resistances of the ion-sensitive barrel were between 50 and $100 \mathrm{G} \Omega$. $\left[\mathrm{Na}^{+}\right]_{\mathrm{i}}$ was determined by comparing the voltage of the pure ion signal obtained upon withdrawing the electrode from the cells into the bath fluid with the voltage obtained upon changing the nomal Krebs solution to solutions containing no $\mathrm{Ca}^{2+}$ and different $\mathrm{Na}^{+}$concentrations $(1,3,12$ and $60 \mathrm{mM}$ ) with a variable background of $\mathrm{K}^{+}$to keep the sum of $\mathrm{Na}^{+}$and $\mathrm{K}^{+}$at $150 \mathrm{mM}$. In these solutions, the $\mathrm{Na}^{+}$-sensitive microelectrodes had slopes of $42-55 \mathrm{mV}$ for a tenfold change in $\mathrm{Na}^{+}$at concentrations above $20 \mathrm{mM}$. In lower $\mathrm{Na}^{+}$-concentrations the slopes were reduced, possibly due to interference with other ions. The selectivity ratios for the $\mathrm{Na}^{+}$-ligand (ETH 227) containing a small amount of $\mathrm{K}^{+}$-tetrachlorophenylborate were in accordance with a previous study: ${ }^{19} \mathrm{Ca}: \mathrm{Na}: \mathrm{K}=2-4: 1: 0.025$.

$\left[\mathrm{Cl}^{-}\right]_{\mathrm{i}}$ was determined using a $\mathrm{Cl}^{-}$-sensitive ion exchanger (W-P Instruments, IE-170). These electrodes were calibrated either in pure $\mathrm{KCl}$-solutions or in solutions containing $\mathrm{KCl}$ in different concentrations and $\mathrm{Na}^{+}$-glucuronate in order to keep the ionic strength constant. ${ }^{32}$ The slope of the electrodes was $50.0 \pm 3.0 \mathrm{mV}$ (mean $\pm \mathrm{SD} ; n=25) . \quad \mathrm{KCl}$
(200 $\mathrm{mM}$ ) was used as internal reference solution; the reference barrel contained $0.5 \mathrm{~mol} / 1 \mathrm{~K}^{+}$-sulphate. Due to the difficulties in determining the exact level of free intracellular $\mathrm{Cl}^{-}$-concentrations (unknown interference with intracellular anions and anionleakage from the reference barrel), data concerning intracellular $\mathrm{Cl}^{-}$-levels will be given both in voltage of the ion signal $\left(\mathrm{V}_{\mathrm{C}}\right)^{2}$ and in free intracellular $\mathrm{Cl}^{-}$-concentrations determined on the basis of calibration curves with pure $\mathrm{KCl}$-solutions.

All values of intracellular $\mathrm{Na}^{+}$and $\mathrm{Cl}^{-}$as well as extra- and intracellular $\mathrm{K}^{+}$refer to free ion concentrations. A conversion into ion activities was not performed.

\section{RESULTS}

\section{General observations}

After impalement of a neuron, it usually took several minutes before the intracellular free ion concentrations reached stable values. During this time, transient decreases of $\left[\mathrm{K}^{+}\right]_{i}$ and increases of $\left[\mathrm{Na}^{+}\right]_{i}$ were often observed, which were probably due to injury leaks created by the electrode penetration. $\left[\mathrm{Cl}^{-}\right]$was stable or showed small shifts in either direction during this "sealing"-period. However, if a stable situation was reached, it was possible to record intracellularly for more than $1 \mathrm{~h}$ without signs of cellular deterioration. Data obtained under such conditions are listed in Table 1. Resting membrane potentials, action potential amplitudes and $\left[\mathrm{K}^{+}\right]_{\mathrm{i}}$ were slightly higher, and $\left[\mathrm{Na}^{+}\right]$lower, as compared to a preliminary report. ${ }^{4}$ This difference is probably the expression of an improved impalement-technique and finer electrode tips.

\section{Effects of carbachol}

Application of carbachol ( 50 or $100 \mu \mathrm{M}$ ) for 45 or $60 \mathrm{~s}$ resulted in a depolarization of the membrane that usually switched into a hyperpolarization after the end of the carbachol-superfusion. These findings made by intracellular recordings of the membrane potential using the reference channel of the ionsensitive microelectrodes confirm previous data obtained by an extracellular electrode system. ${ }^{7}$ The membrane potential changes were accompanied by decreases of $\left[\mathrm{K}^{+}\right]_{\mathrm{i}}$ in the range of $7-40 \mathrm{mM}$ as observed with $\mathrm{K}^{+}$-sensitive microelectrodes. A neuron in which during $50 \mu \mathrm{M}$ carbachol $(45 \mathrm{~s}),\left[\mathrm{K}^{+}\right]$, decreased from 144 to $116 \mathrm{mM}$ and the membrane depolarized to $-20 \mathrm{mV}$ is illustrated in Fig. I. Immediately after the end of the carbachol application and

Table 1. Free intracellular ion concentrations of neurons in rat sympathetic ganglion. Data were taken $10 \mathrm{~min}$ after impalement. Neurons with resting membrane potentials below $-40 \mathrm{mV}$ were discarded (mean $\pm \mathrm{SD}$ )

\begin{tabular}{lccc}
\hline \multicolumn{1}{c}{ lon } & $\mathrm{K}^{+}$ & $\mathrm{Na}^{1}$ & $\mathrm{Cl}$ \\
Free intracellular concentrations (mM) & $129.7 \pm 12.9$ & $7.7 \pm 3.3$ & $40.4 \pm 6.0$ \\
Resting membrane potential $(\mathrm{mV})$ & $-50.7 \pm 7.6$ & $-47.3 \pm 5.8$ & $-49.1 \pm 5.4$ \\
Action potential amplitude $(\mathrm{mV})$ & $82.9 \pm 15.8$ & $76.4 \pm 13.0$ & $91.8 \pm 14.1$ \\
E $_{\text {las }}(\mathrm{mV})$ & -80 & +76 & -27 \\
Number of observations & 48 & 22 & 39 \\
\hline
\end{tabular}




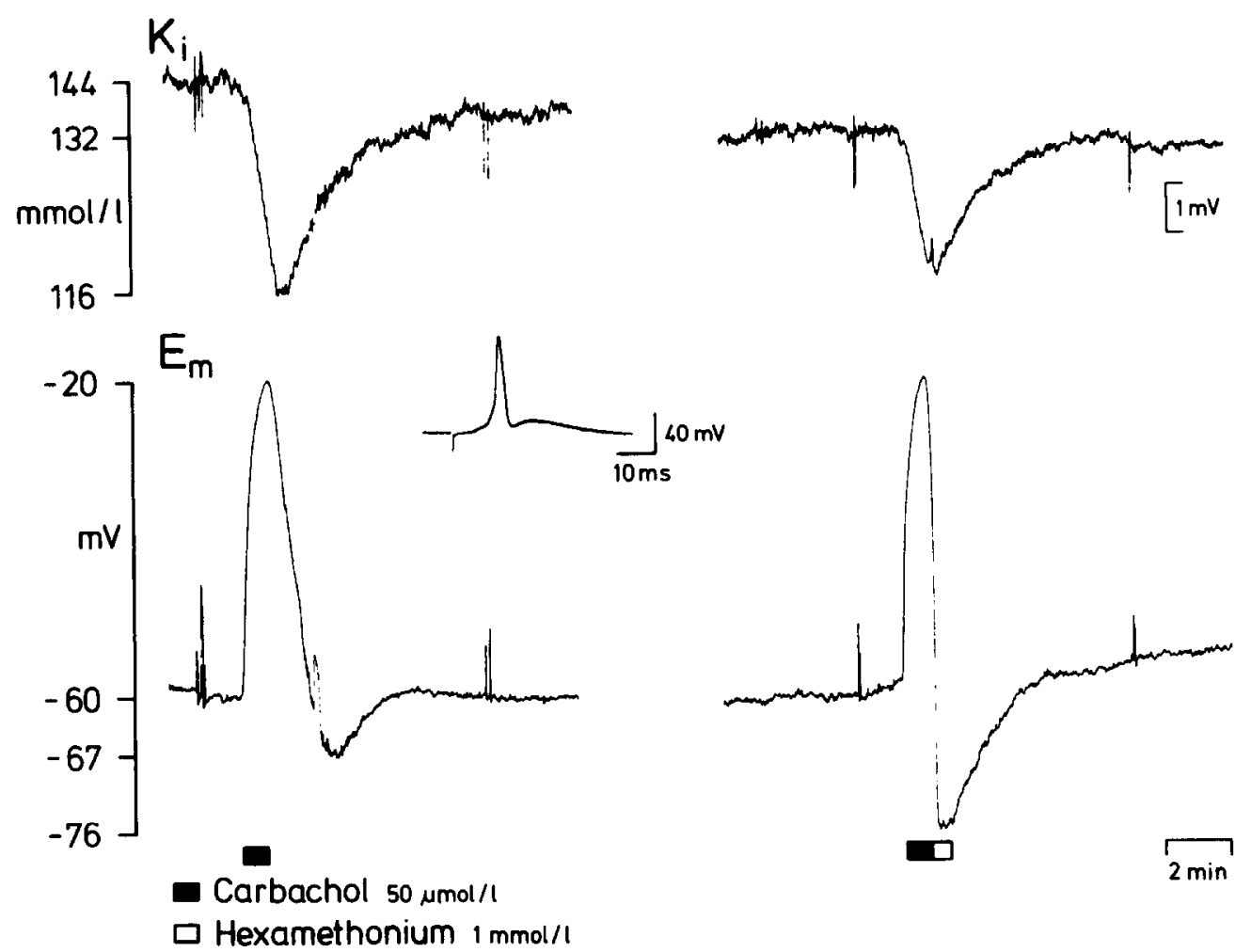

Fig. 1. Effects of carbachol on free intracellular $K^{+}$-concentration $\left(K_{i}\right)$ and membrane potential $\left(E_{m}\right)$ of a rat sympathetic neuron. The slow membrane potential changes upon bath application of carbachol were accompanied by transient decreases of $\mathrm{K}_{\mathrm{i}}$. Hexamethonium was added after the second carbachol application to block the nicotinic receptors. Note that the post-carbachol hyperpolarization is much larger in the presence of hexamethonium. ${ }^{5}$ Furthermore, there is a smaller decrease of $\mathrm{K}_{\mathrm{i}}$ in the presence of hexamethonium due to the faster recovery of the membrane potential. The deflections on both $E_{m}$ - and $\mathbf{K}_{\mathrm{i}}$-traces are due to electrically elicited action potentials. A typical example of such an action potential with an amplitude of $95 \mathrm{mV}$ is shown in the inset.

clearly before the lowermost $\left[\mathrm{K}^{+}\right]_{\text {- }}$-value was reached, the membrane potential turned into a hyperpolarization to $-67 \mathrm{mV}$ and then returned to its control level of $-60 \mathrm{mV}$. During this period, a forced reuptake of $\mathrm{K}^{+}$occurred which lasted about $8 \mathrm{~min}$. After a second application of carbachol, hexamethonium was used to block the nicotinic receptors. This experimental procedure, which is supposed to abbreviate passive ion fluxes at the time of carbachol wash-out, ${ }^{7.27}$ accelerated the post-carbachol hyperpolarization. In agreement with the shorter period of membrane depolarization, the $\left[\mathrm{K}^{+}\right]_{\mathrm{i}}$ decrease was only $14 \mathrm{mM}$, i.e. from 132 to $118 \mathrm{mM}$.

The effects of carbachol on $\left[\mathrm{Na}^{+}\right]_{i}$ mirrored those on $\left[\mathrm{K}^{+}\right]_{i}$. The transient increases of $\left[\mathrm{Na}^{+}\right]_{i}$ were in the same range $(7-40 \mathrm{mM})$ as the $\left[\mathrm{K}^{+}\right]_{1}$-decreases when compared for cells with comparably large membrane potentials. In the example illustrated in Fig. 2, $100 \mu \mathrm{M}$ carbachol (45s) depolarized the membrane to $-15 \mathrm{mV}$. This effect was accompanied by an increase of $\left[\mathrm{Na}^{+}\right]_{i}$ by about $20 \mathrm{mM}$. The decreasing slope of $\left[\mathrm{Na}^{+}\right]_{i}$, visible before the first carbachol application, was due to a "sealing"-phase of the cell membrane (see above). A smaller carbachol dose $(50 \mu \mathrm{M}, 45 \mathrm{~s})$ resulted in a relatively smaller membrane depolarization and a smaller increase of
$\left[\mathrm{Na}^{+}\right]_{i}$. In this experiment no hexamethonium was added during the washing phase. Therefore, only a small post-carbachol hyperpolarization was visible (compare with Fig. 3). In general, observations using ion-sensitive microelectrodes resemble previous data obtained by Brown and Scholfield, ${ }^{5,6.27}$ who have used flame photometry or radioactive labelling in order to observe the kinetics of $\mathrm{Na}^{+}$- and $\mathrm{K}^{+}$-movements in rat sympathetic ganglia pretreated with carbachol.

Experiments with tetrodotoxin and veratridine were performed in order to characterize the nature of the carbachol-induced increases of $\left[\mathrm{Na}^{+}\right]_{i}$. Veratridine $(60 \mu \mathrm{M}, 30 \mathrm{~s})$ had similar effects on both the membrane potential and $\left[\mathrm{Na}^{+}\right]_{\mathrm{i}}$ when compared to carbachol (Fig. 3). A membrane depolarization to $-21 \mathrm{mV}$ was followed by a post-veratridine hyperpolarization to $-73 \mathrm{mV}$. $\left[\mathrm{Na}^{+}\right]_{\mathrm{i}}$ increased from 4 to $50 \mathrm{mM}$ and recovered to $4 \mathrm{mM}$ after $9 \mathrm{~min}$. Application of carbachol $(50 \mu \mathrm{M}, 45 \mathrm{~s})$ on the same cell also resulted in a typical, although smaller increase of $\left[\mathrm{Na}^{+}\right]_{i}$. During superfusion of the ganglion with tetrodotoxin $(1 \mu \mathrm{M})$, a complete blockade of the veratridine response occurred, whereas the increase of $\left[\mathrm{Na}^{+}\right]_{\mathrm{i}}$ during carbachol persisted. These results indicate that carbachol-induced elevations of $\left[\mathrm{Na}^{+}\right]_{\mathrm{i}}$ are due to the activation of receptor-linked 


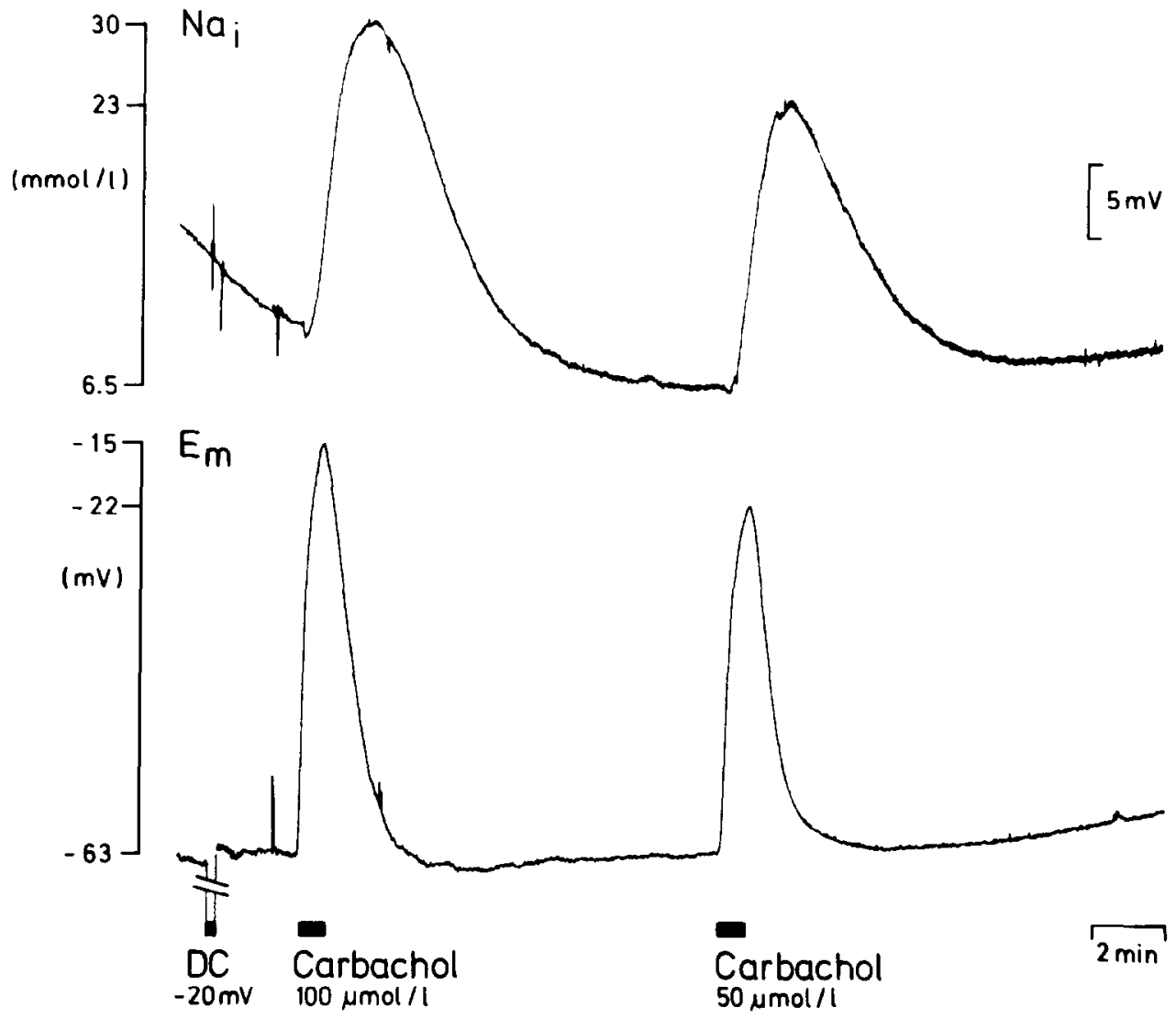

Fig. 2. Effects of carbachol on free intracellular $\mathrm{Na}^{+}$-concentration $\left(\mathrm{Na}_{i}\right)$ and membrane potential $\left(\mathrm{E}_{\mathrm{m}}\right)$ of a rat sympathetic neuron. The depolarization upon bath application of $100 \mu \mathrm{M}$ carbachol was accompanied by a considerable transient increase of $\mathrm{Na}_{\mathrm{i}}$. A smaller depolarization of the membrane, accompanied by a smaller increase of $\mathrm{Na}_{\mathrm{i}}$, was induced by $50 \mu \mathrm{M}$ carbachol. The initial decrease of $\mathrm{Na}_{\mathrm{i}}$ is due to a "sealing"-phase of the cell. A d.c.-pulse $(-20 \mathrm{mV})$ was applied between the bath and main ground to test the gain adjustment of the amplifier.

$\mathrm{Na}^{+}$-channels and not due to voltage-dependent $\mathrm{Na}^{+}$-channels. ${ }^{23}$

Finally, effects of carbachol have been tested on $\left[\mathrm{Cl}^{-}\right]_{1}$. Such experiments did not reveal a carbacholinduced change of $\left[\mathrm{Cl}^{-}\right]_{\mathrm{i}}$ (Fig. 4).

\section{Effects of $\gamma$-aminobutyric acid}

$\gamma$-Aminobutyric acid also depolarizes isolated rat sympathetic ganglion cells.' Our observations using ion-sensitive microelectrodes show that the depolarization by GABA was accompanied by a decrease of $\left[\mathrm{Cl}^{-}\right]_{i}$ and $\left[\mathrm{K}^{+}\right]_{i}$ and no change of $\left[\mathrm{Na}^{+}\right]_{i}$. Experiments using $\mathrm{Cl}^{-}$-sensitive microelectrodes revealed that the baseline level of $\left[\mathrm{Cl}^{-}\right]_{i}$ in rat sympathetic neurons is higher than expected from a passive distribution (see Table 1). These data, therefore, confirm previous assumptions about $\left[\mathrm{Cl}^{-}\right]_{i}$ in these cells. ${ }^{1}$ In all cells tested $(n=39)$, GABA produced a typical decrease of $\left[\mathrm{Cl}^{-}\right]_{\mathrm{i}}$ in the range of $4-16 \mathrm{mM}$, whereas carbachol had no effect (see Fig. 4).

$\gamma$-Aminobutyric acid transiently decreased $\left[\mathrm{K}^{+}\right]_{\mathrm{i}}$ in the range of 4-20 $\mathrm{mM}$ depending on the magnitude of the membrane depolarization. A typical example of simultaneous measurements of both $\left[\mathrm{K}^{+}\right]_{i}$ and membrane potential upon application of $50 \mu \mathrm{M}$
GABA (45s), combined with the corresponding measurements of $\left[\mathrm{K}^{+}\right]_{\mathrm{e}}$ and the membrane potential of a glial cell (in different ganglia), is illustrated in Fig. 5. The membrane depolarization of $25 \mathrm{mV}$ is accompanied by a decrease of $\left[\mathrm{K}^{+}\right]_{i}$ by about $6 \mathrm{mM}$ for each of the two applications of GABA. $\left[\mathrm{K}^{+}\right]_{\mathrm{e}}$ at the same time increased from 6 to $7 \mathrm{mM}$. In general, increases of $\left[\mathrm{K}^{+}\right]_{e}$ were in the range of $1-2 \mathrm{mM}$. The kinetics of the extra- and the intracellular $\mathrm{K}^{+}$-concentration changes were very similar to each other and different to the carbachol-induced changes of extra- and intracellular $\mathrm{K}^{+}$(see below). A GABA-induced neuronal $\mathrm{K}^{+}$-release was also confirmed by intracellular recordings from glial cells. A typical example is given in the lower inset of Fig. 5. The membrane of this glial cell was depolarized from -68 to $-63 \mathrm{mV}$, from which an increase of $\left[\mathrm{K}^{+}\right]_{e}$ of about $1 \mathrm{mM}$ can be calculated under the assumption that the glial cell membrane behaves like a $\mathrm{K}^{+}$-electrode. (This calculation can be performed even if the membrane of this glial cell was partially injured by the impalement as indicated by the low resting potential).

In contrast to alterations of $\left[\mathrm{Cl}^{-}\right]_{i},\left[\mathrm{~K}^{+}\right]_{e}$ and $\left[\mathrm{K}^{+}\right]_{\mathrm{i}}$, no changes of $\left[\mathrm{Na}^{+}\right]_{\mathrm{i}}$ could be detected in the presence of GABA. A neuron, in which subsequent 


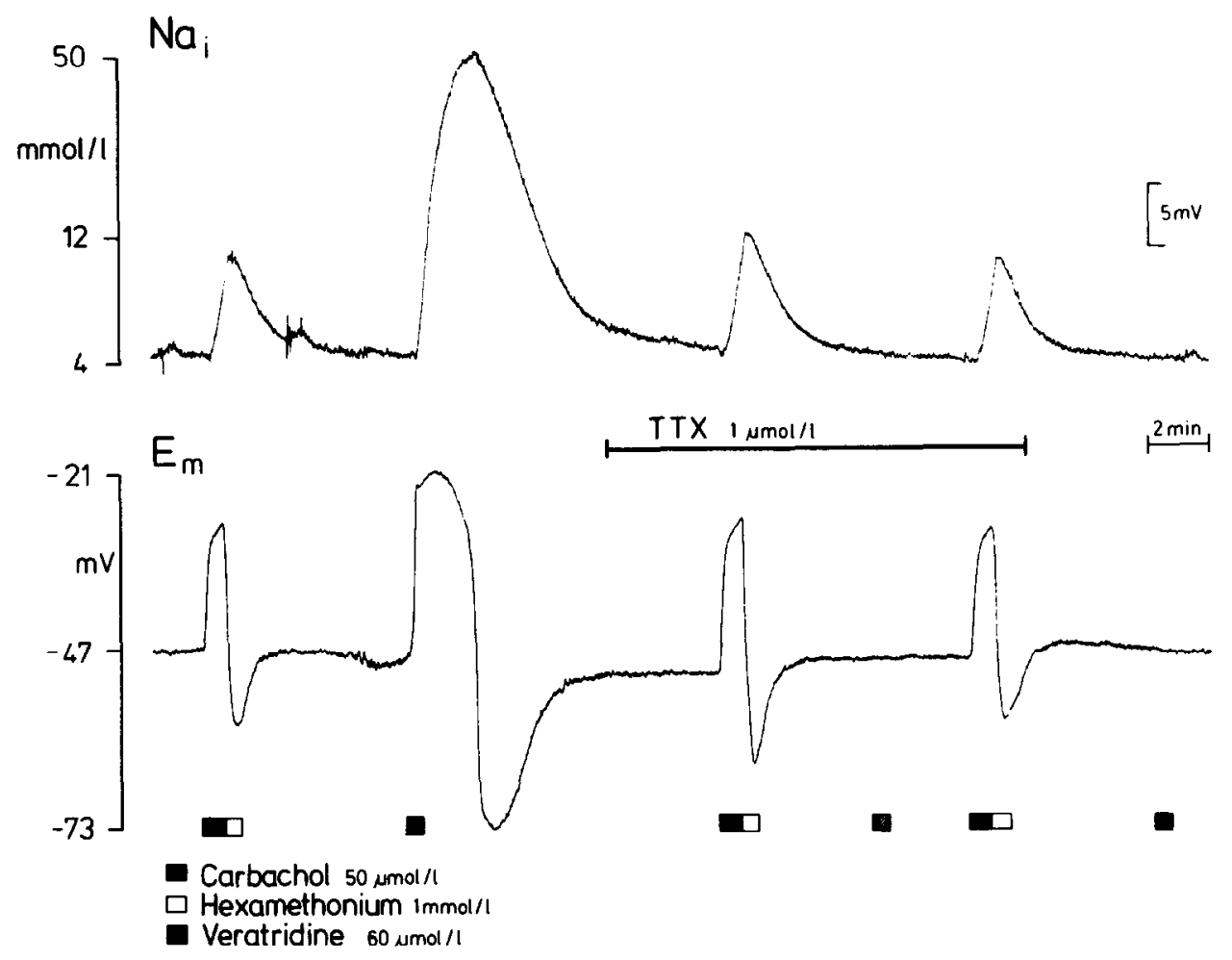

Fig. 3. Effects of carbachol and veratridine on intracellular $\mathrm{Na}^{+}$-concentration $\left(\mathrm{Na}_{i}\right)$ and membrane potential $\left(\mathrm{E}_{\mathrm{m}}\right)$ in the presence of tetrodotoxin (TTX). Note that the effects of veratridine and carbachol on both the membrane potential and $\mathrm{Na}_{\mathrm{i}}$ were very similar to each other in spite of different amplitudes. In the presence of TTX, the carbachol response was unaffected whereas the veratridine response was totally blocked.
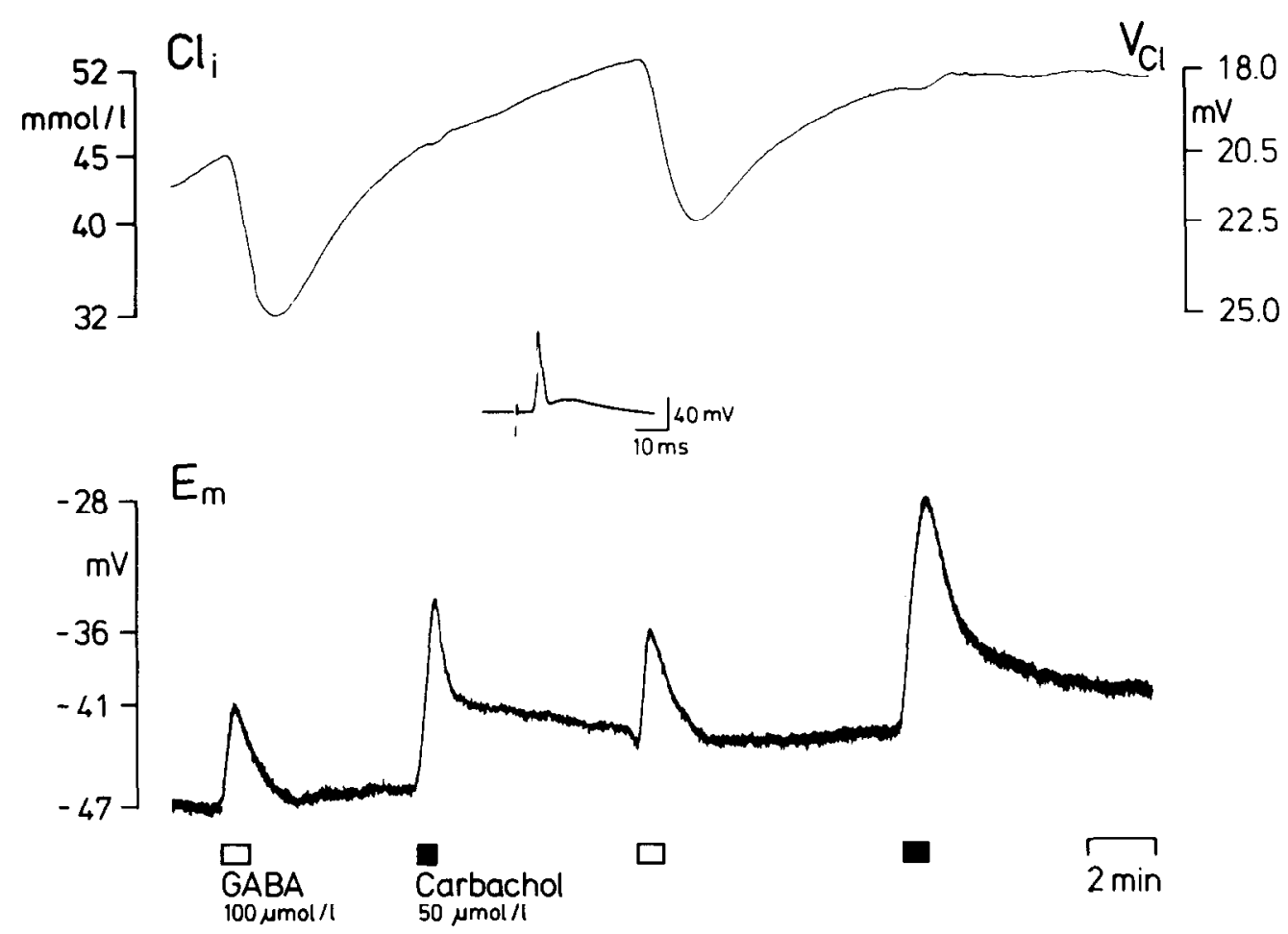

Fig. 4. Effects of carbachol and GABA on free intracellular $\mathrm{Cl}^{-}$-concentration $\left(\mathrm{Cl}_{\mathrm{i}}\right)$ and membrane potential $\left(E_{m}\right)$. The first membrane depolarization (during GABA) is accompanied by a transient decrease of $\mathrm{Cl}_{\mathrm{i}}$ from 45 to $32 \mathrm{mM}$. In contrast, carbachol-administration evoked no change of $\mathrm{Cl}_{\mathrm{i}}$ in spite of a larger membrane depolarization. The inset shows an action potential induced by orthodromic stimulation of the ganglion at the beginning of the recording. Calibrations of the $\mathrm{Cl}^{-}$-traces are given in free ion concentrations $\left(\mathrm{Cl}_{\mathrm{i}}\right)$ and in voltage of the ion signal $\left(\mathrm{V}_{\mathrm{Cl}}\right)$ (registration $\mathrm{Cl}_{\mathrm{i}}$ filtered above $0.1 \mathrm{~Hz}$ ). 

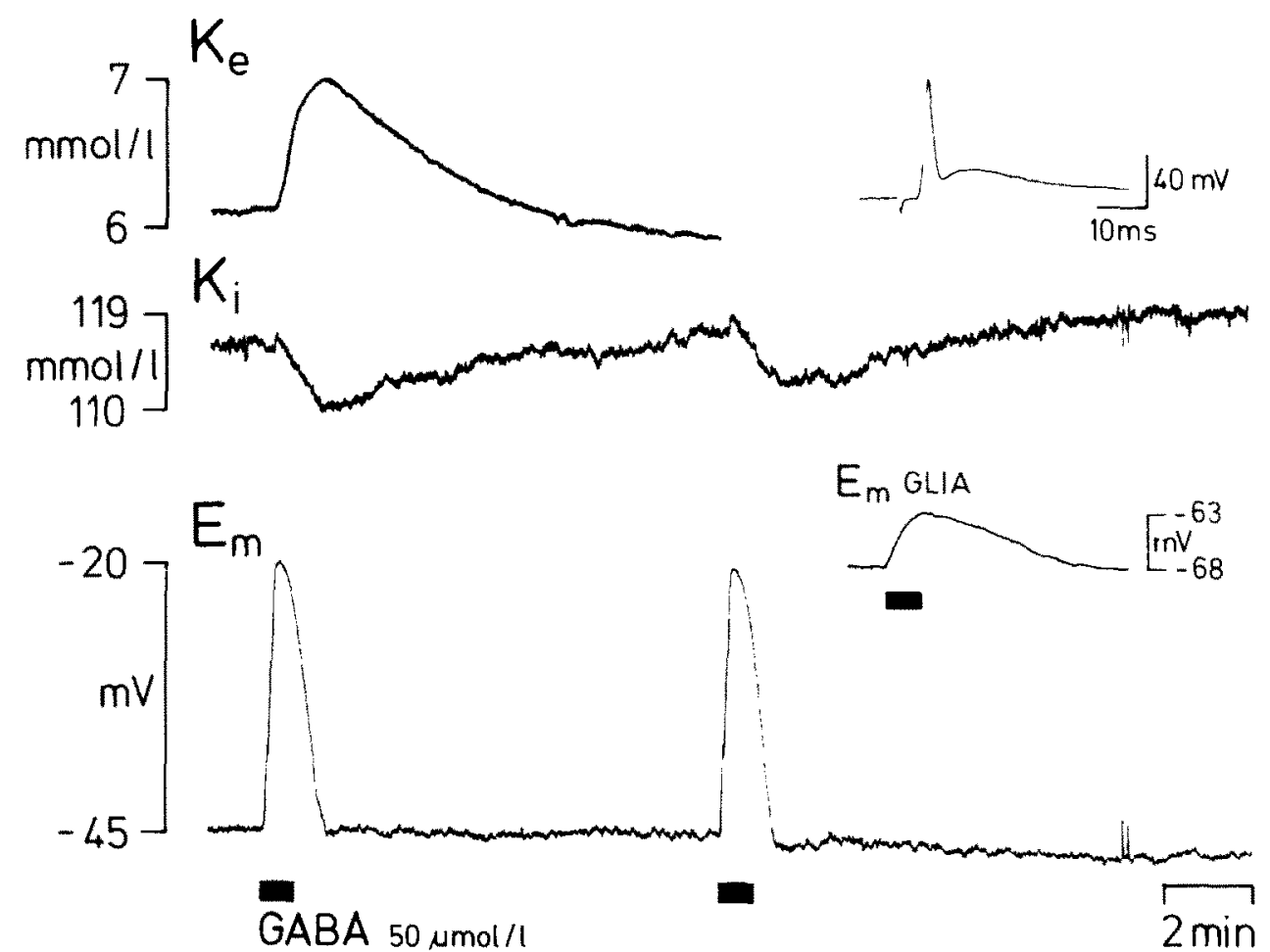

Fig. 5. Effects of GABA on free extra- and intracellular $K^{+}$-concentrations $\left(K_{c}, K_{i}\right)$ and membrane potential $\left(\mathrm{E}_{\mathrm{m}}\right)$ of a neuron and a glial cell. Depolarizations of about $25 \mathrm{mV}$ upon bath application of GABA were accompanied by transient decreases of $\mathrm{K}_{\mathrm{i}}$ of about $6 \mathrm{mM}$. In addition, $\mathrm{K}_{\mathrm{e}}$ increased from 6 to $7 \mathrm{mM}$. Note that the kinetics of the changes of $\mathrm{K}_{\mathrm{i}}$ and $\mathrm{K}_{\mathrm{c}}$ are very similar to each other. The upper inset shows an action potential of $95 \mathrm{mV}$ amplitude orthodromically evoked $8 \mathrm{~min}$ after the second GABA application. The lower inset illustrates that also glial cells were depolarized in the presence of GABA (recording from a different ganglion).

applications of carbachol $(50 \mu \mathrm{M}, 1 \mathrm{~min})$ and GABA $(100 \mu \mathrm{M}, 45 \mathrm{~s})$ resulted in membrane depolarizations between 20 and $25 \mathrm{mV}$, is illustrated in Fig. 6 . In

(mmol/1)

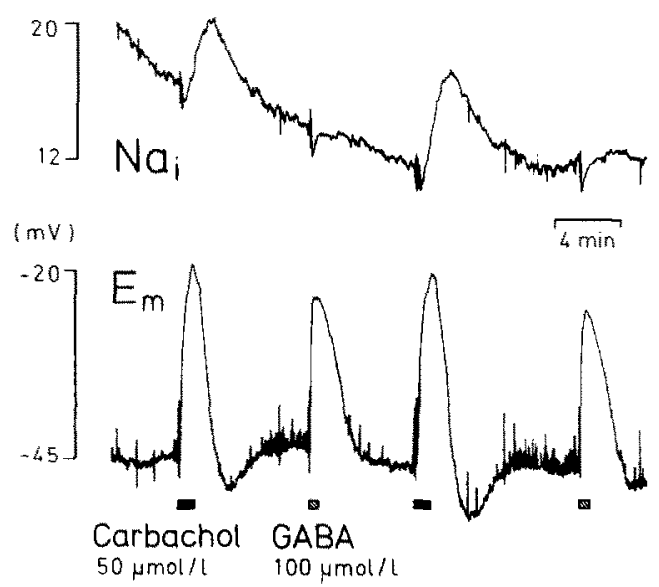

Fig. 6. Effects of carbachol and GABA on free intracellular $\mathrm{Na}^{+}$-concentration $\left(\mathrm{Na}_{i}\right)$ and membrane potential $\left(\mathrm{E}_{\mathrm{m}}\right)$ of a rat sympathetic neuron. Application of carbachol resulted in the typical membrane depolarization and a $\mathrm{Na}_{i}$-increase. However, GABA has no effect on $\mathrm{Na}_{i}$ in spite of a membrane depolarization comparable in amplitude to that during carbachol. The $\mathrm{Na}_{i}$-decrease before and after the first carbachol application is due to a "sealing"-phase of the cell. The noise on both the $\mathrm{Na}_{\mathrm{i}}$ and $\mathrm{E}_{\mathrm{m}}$ trace is partly due to spontaneous activity of the neuron. contrast to the carbachol-induced increase of $\left[\mathrm{Na}^{+}\right]$, no effect of GABA on $\left[\mathrm{Na}^{+}\right]$, was detected. The decline of $\left[\mathrm{Na}^{+}\right]_{i}$ at the beginning of the measurements, again. is due to a "sealing"-phase of the cell.

\section{Effects of ouabain}

In order to study the mechanisms leading to the restoration of ion distributions after the action of neurotransmitters, effects of ouabain have been investigated. We have already shown ${ }^{4}$ that ouabain reversibly blocked the reuptake of $\mathrm{K}^{+}$previously released by carbachol. Similar data were obtained with $\mathrm{Na}^{+}$-sensitive microelectrodes (Fig. 7). In this neuron, two control applications of carbachol illustrate the typical effects on both the membrane potential and $\left[\mathrm{Na}^{+}\right]$. Upon subsequent addition of $300 \mu \mathrm{M}$ ouabain, the membrane depolarized by about $4 \mathrm{mV} .\left[\mathrm{Na}^{+}\right]_{\mathrm{i}}$ increased steadily during this period from 2 to $5 \mathrm{mM}$. Under the assumption that the $\mathrm{Na}^{+} / \mathrm{K}^{+}$-pump is completely blocked at this time, this increase of $\left[\mathrm{Na}^{+}\right]$would correspond to the passive influx of $\mathrm{Na}^{+}$into the cell via the leak conductance of the membrane. Application of carbachol in the presence of ouabain resulted in a membrane depolarization and a rise in $\left[\mathrm{Na}^{+}\right]_{\text {, similar }}$ to the control measurements. However, both the membrane hyperpolarization and the $\mathrm{Na}^{+}$-extrusion 

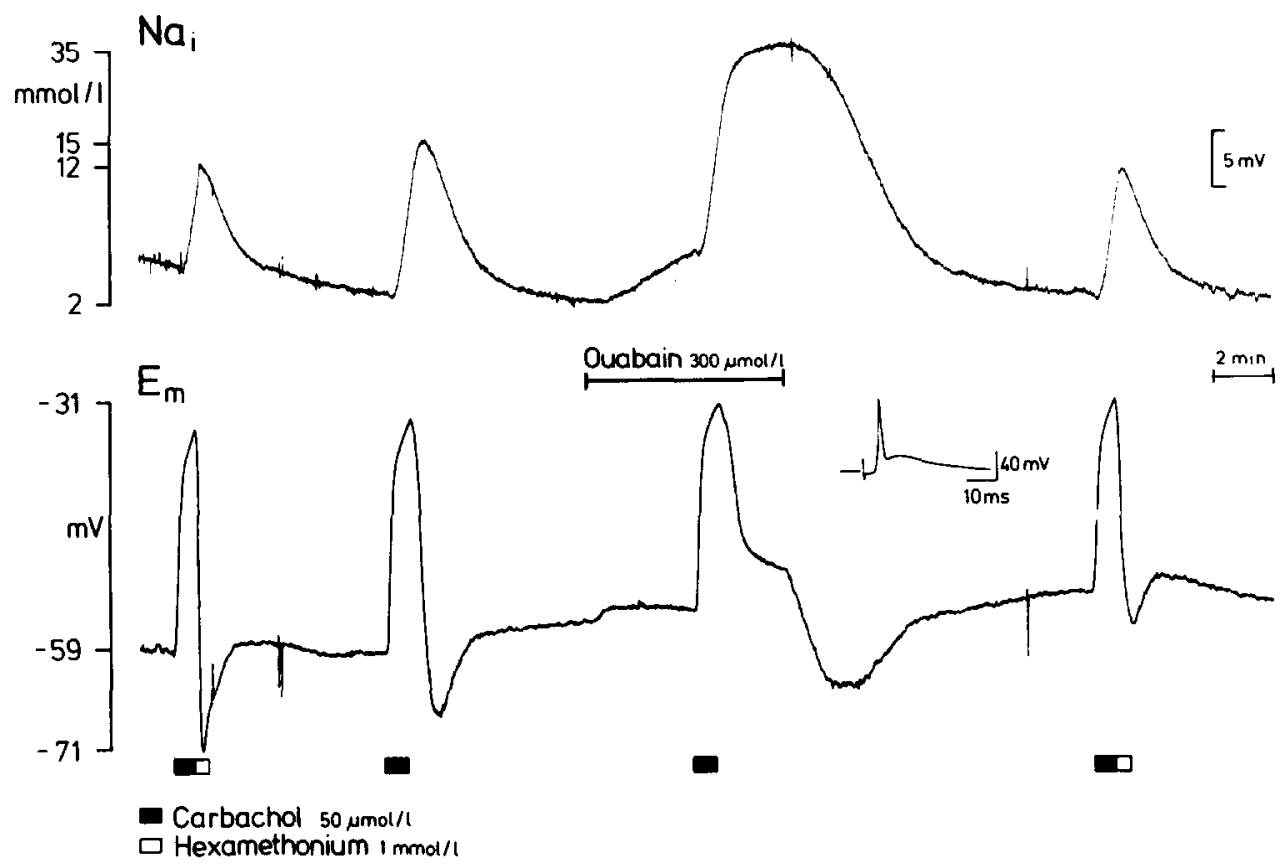

Fig. 7. Effects of ouabain on carbachol-induced changes of free intracellular $\mathrm{Na}^{+}$-concentration $\left(\mathrm{Na}_{\mathrm{i}}\right)$ and membrane potential $\left(\mathrm{E}_{\mathrm{m}}\right)$. After two control applications of carbachol, ouabain was added to the superfusion fluid. This resulted in a depolarization of the membrane by about $4 \mathrm{mV}$ accompanied by an increase of $\mathrm{Na}_{\mathrm{i}}$. Membrane potential recovery after carbachol is incomplete in the presence of ouabain. In addition, the $\mathrm{Na}^{+}$-extrusion after carbachol is totally blocked by ouabain. After washout of ouabain, $\mathrm{Na}_{\mathrm{i}}$ returned to baseline level accompanied by a corresponding hyperpolarization of the membrane. Inset shows an action potential with an amplitude of $100 \mathrm{mV}$ electrically elicited after the recovery from ouabain (see deflection on $\mathrm{E}_{\mathrm{m}}$ - and $\mathrm{Na}_{i}$-trace).

normally observable after the end of the carbacholsuperfusion, were completely absent. The actions of ouabain were reversible as judged by the fall in $\left[\mathrm{Na}^{+}\right]_{i}$ and the membrane hyperpolarization observed immediately after washout of ouabain.

The observation that the GABA-induced neuronal $\mathrm{K}^{+}$-release is not accompanied by an increase of $\left[\mathrm{Na}^{+}\right]_{i}$ raises the question, if the $\mathrm{Na}^{+} / \mathrm{K}^{+}$-pump contributes to the $\mathrm{K}^{+}$-reuptake after the end of the GABA-application. This problem was investigated by a study of the effects of ouabain on the kinetics of alterations in $\left[\mathrm{K}^{+}\right]_{\mathrm{e}}$ observable during and after the action of GABA. A typical example from such experiments is shown in Fig. 8. In normal Krebs' solution, application of GABA resulted in a transient elevation of $\left[\mathrm{K}^{+}\right]_{e}$ from the baseline level of 6.0 to $7.8 \mathrm{mM}$. The return to baseline lasted about $6 \mathrm{~min}$. Application of carbachol increased $\left[\mathrm{K}^{+}\right]_{e}$ from 6.0 to $9.0 \mathrm{mM}$; recovery to baseline in this case took only about $2 \mathrm{~min}$ and was followed by a typical $\left[\mathrm{K}^{+}\right]_{\mathrm{e}}$-undershoot for about $6 \mathrm{~min}$ (see also ref. 15). Such a $\left[\mathrm{K}^{+}\right]_{\mathrm{e}}$-undershoot was never observed after GABA-applications. Afterwards, $300 \mu \mathrm{M}$ ouabain transiently increased $\left[\mathrm{K}^{+}\right]_{e}$ to $6.2 \mathrm{mM}$ (see dotted line on the middle trace). It was observed, that the kinetics of the GABA-induced rise and recovery of $\left[\mathbf{K}^{+}\right]_{e}$ in the presence of ouabain were similar to the control applications, whereas the $\left[\mathrm{K}^{+}\right]_{\mathrm{e}}$-recovery after carbachol was markedly delayed and the $\left[\mathrm{K}^{+}\right]_{\mathrm{e}^{-}}$ undershoot was completely blocked.

\section{Effects of furosemide}

The absence of an action of GABA upon $\left[\mathrm{Na}^{+}\right]_{i}$ as well as the lack of ouabain-effects on the reuptake of GABA-released $\mathrm{K}^{+}$indicate, that the restoration of the $\mathrm{K}^{+}$-gradient after the action of GABA involves a $\mathrm{K}^{+}$-reuptake insensitive to ouabain and different from the $\mathrm{Na}^{+} / \mathrm{K}^{+}$-pump. In order to investigate the nature of this process, effects of furosemide $(0.5-1 \mathrm{mM})$ on $\left[\mathrm{K}^{+}\right]_{\mathrm{e}},\left[\mathrm{K}^{+}\right]_{i}$ and $\left[\mathrm{Cl}^{-}\right]_{1}$ were investigated. Furosemide is known to block a $\mathrm{Cl}^{-}$-dependent $\mathrm{K}^{+}$-influx in erythrocytes, ${ }^{13.14}$ ascites tumor cells, ${ }^{18}$ squid axon, ${ }^{26}$ and a variety of other cultured cells. ${ }^{3}$

Measurements with extracellularly located $\mathrm{K}^{+}$sensitive microelectrodes revealed that furosemide did not alter the amplitude and the kinetics of the $\mathrm{K}^{+}$-response obtained by an application of carbachol. In particular, the post-carbachol $\left[\mathrm{K}^{+}\right]_{e}-$ undershoot was not changed (Fig. 9B). On the other hand, furosemide reduced the amplitude of the rise of $\left[\mathrm{K}^{+}\right]_{e}$ resulting from GABA-administration and slowed down the post-GABA $\left[\mathrm{K}^{+}\right]_{e}$-recovery (Fig. 9B). Intracellular measurements with $\mathrm{K}^{+}$-sensitive microelectrodes showed that furosemide strongly delayed or completely inhibited the reuptake of $\mathrm{K}^{+}$ released during the action of GABA (Fig. 9A).

Two of the experiments in which effects of furosemide on $\left[\mathrm{Cl}^{-}\right]_{i}$ have been tested are illustrated in Fig. 10. It can be seen that a short application of furosemide $(0.5 \mathrm{mM} ; 6 \mathrm{~min})$ clearly delayed the re- 


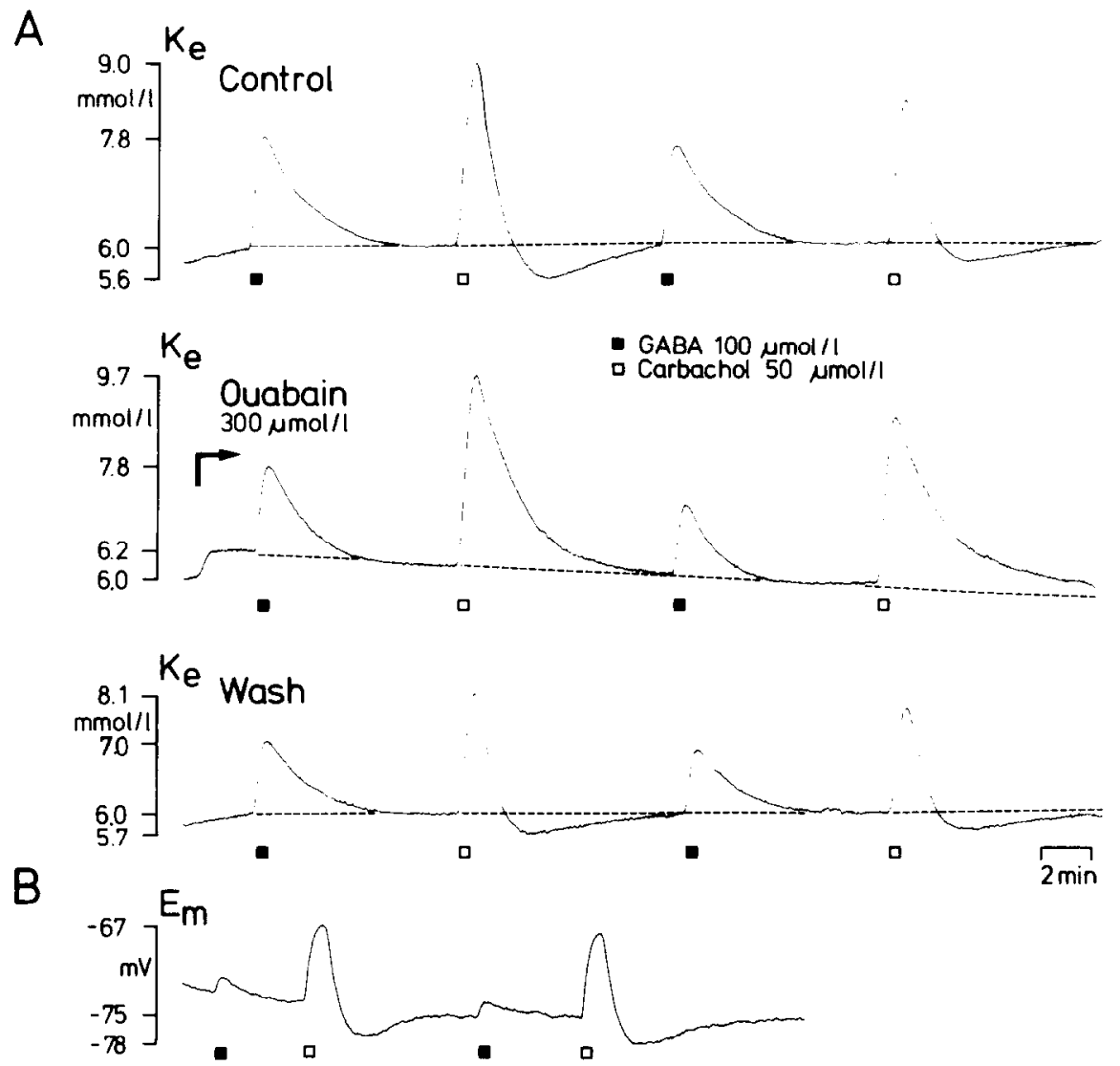

Fig. 8. (A) Effects of carbachol and GABA on free extracellular $\mathrm{K}^{+}$-concentration $\left(\mathrm{K}_{\mathrm{e}}\right)$ in the presence of ouabain. In the control period, GABA transiently elevated $\mathrm{K}_{t}$ by about $2 \mathrm{mM} . \mathrm{K}_{\mathrm{e}}$ increases upon carbachol were larger. However, the kinetics of the $\mathrm{K}_{\mathrm{e}}$ recovery after carbachol are different to the $\mathrm{K}_{\mathrm{e}}$ recovery after GABA (see $\mathrm{K}_{\mathrm{e}}$-undershoot). In the presence of ouabain the carbachol-induced $\mathrm{K}_{\mathrm{e}}$-undershoot is blocked, whereas the kinetics of the $\mathrm{K}_{\mathrm{e}}$ recovery after GABA is unchanged. These effects of ouabain are fully reversible. (B) Effects of GABA and carbachol on the membrane potential $\left(E_{m}\right)$ of a glial cell. Note that the kinetics of $\mathrm{K}_{\mathrm{e}}$-measurements by means of ion-sensitive microelectrodes and glial-cell membrane potential resemble each other.

uptake of $\mathrm{Cl}^{-}$released upon GABA-superfusion (Fig. 10A). This effect was reversible within $30 \mathrm{~min}$. Longer applications of furosemide $(10-20 \mathrm{~min}) \mathrm{re}$ sulted in a complete blockade of the post-GABA $\mathrm{Cl}$-uptake for about $2 \mathrm{~h}$ (Fig. 10B). In addition to effects on the reuptake of $\mathrm{K}^{+}$and $\mathrm{Cl}^{-}$released during the action of GABA, furosemide also decreased the rise of $\left[\mathrm{K}^{+}\right]_{\mathrm{e}}$ upon GABA and the GABA-induced membrane depolarization (see Figs $9 \mathrm{~A}, \mathrm{~B}$ and $10 \mathrm{~B}$ ). This might he due to a change of the $\mathrm{Cl}^{-}$-equilibrium potential as well as to a block of the GABAassociated $\mathrm{Cl}^{-}$channel (see below).

\section{DISCUSSION}

Firstly, the mechanisms underlying carbacholinduced ion movements will be considered. Carbachol depolarizes rat sympathetic neurons by the activation of nicotinic receptors. These receptors are linked to large cation selective channels ${ }^{33}$ which, in an open state, allow $\mathrm{Na}^{+}$to enter the cell. The increase of $\left[\mathrm{Na}^{+}\right]_{i}$ is therefore due to a receptor-coupled $\mathrm{Na}^{+}$-influx. Activation of voltage-dependent $\mathrm{Na}^{+}$. channels, as the alternative possibility, seems unlikely, since the changes of $\left[\mathrm{Na}^{+}\right]_{i}$ were unaltered in the presence of tetrodotoxin (see Fig. 3). On the other hand, tetrodotoxin prevented $\left[\mathrm{Na}^{+}\right]_{\mathrm{i}}$ from increasing during the action of veratridine, a drug which is known to open voltage-dependent $\mathrm{Na}^{+}$-channels. ${ }^{23}$ The decrease of $\left[\mathrm{K}^{+}\right]_{i}$, which occurred in the presence of carbachol, is the result of both an increase in $\mathrm{K}^{+}$-conductance as well as an increase of the outwardly directed driving force during the membrane depolarization. Several types of $\mathrm{K}^{+}$-permeable membrane channels might contribute to the $\mathrm{K}^{+}$-release, such as receptor-activated cation channcls, lcak channels and also voltage-dependent $\mathrm{K}^{+}$-channels. ${ }^{2}$

The mechanism responsible for the restoration of $\left[\mathrm{Na}^{+}\right]_{\mathrm{i}^{-}}$and $\left[\mathrm{K}^{+}\right]_{\mathrm{i}}$-levels after the carbachol application appears to be the $\mathrm{Na}^{+} / \mathrm{K}^{+}$-pump. This view is supported by the complete inhibition of both the $\mathrm{Na}^{+}$-extrusion and the $\mathrm{K}^{+}$-reuptake in the presence of ouabain. Previous measurements of free intracellular ion concentrations with ion-sensitive microelectrodes in snail ${ }^{30}$ and leech neurons ${ }^{10.11}$ after inhibition of the $\mathrm{Na}^{+} / \mathrm{K}^{+}$-pump gave similar results. 
A

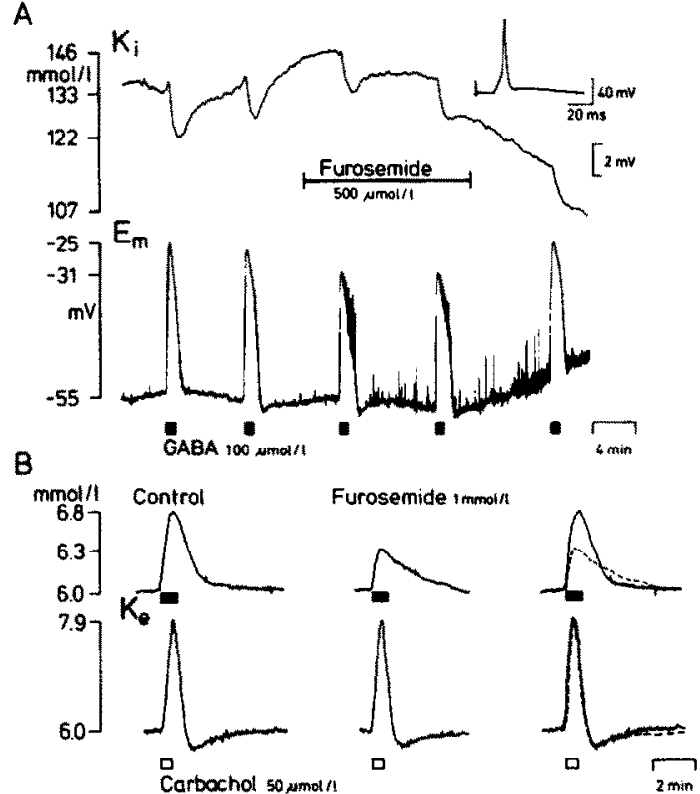

Fig. 9. Effects of furosemide on GABA-induced changes of free extra- and intracellular $\mathrm{K}^{+}$-concentration $\left(K_{e}, K_{i}\right)$. (A) Intracellular recording with a $\mathrm{K}^{+}$-sensitive microelectrode. Furosemide inhibited the reuptake of $\mathrm{K}^{+}$released during the action of GABA. The inset shows an orthodromically elicited action potential taken at the beginning of the recording period. (B) Extracellular recording with a $\mathrm{K}^{+}$-sensitive microelectrode. Furosemide reduced the amplitude of the rise of $K_{e}$ during GABA and slowed down the post-GABA recovery. However, furosemide did not change the post-carbachol $\mathrm{K}_{\mathrm{e}}$-undershoot (see superimposed $\mathrm{K}^{+}$-registrations). The black bar, used to mark a GABA-application, refers to part (A) and (B) (registration of $\mathrm{K}_{\mathrm{i}}$ filtered above $0.1 \mathrm{~Hz}$ ). $\mathrm{F}_{\mathrm{m}}$, membrane potential.

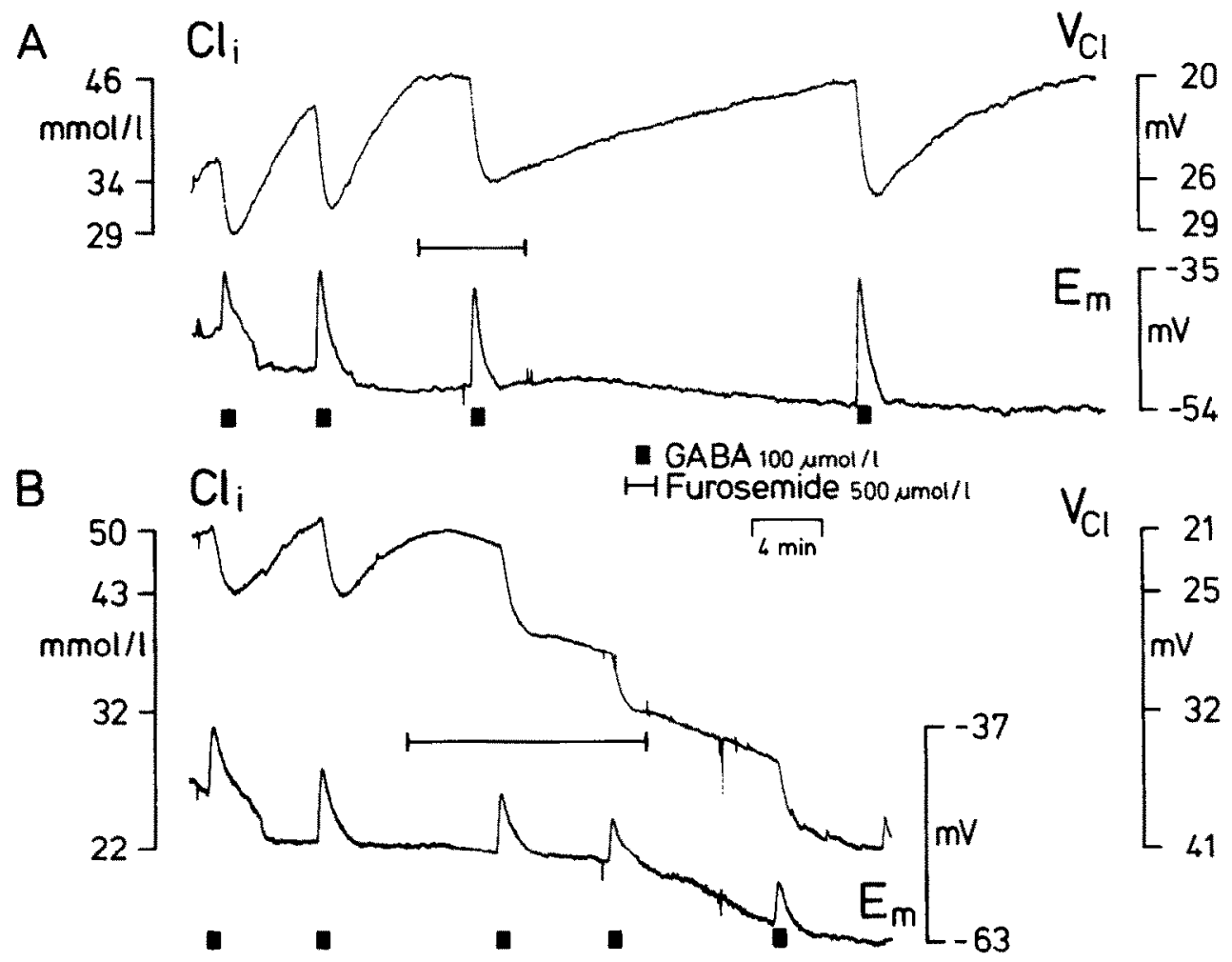

Fig. 10. Effects of furosemide on GABA-induced changes of free intracellular $\mathrm{Cl}^{-}$-concentration ( $\mathrm{Cl}_{\mathrm{i}}$ ). (A) illustrates a short-lasting application of furosemide. Note that the reuptake $\mathrm{Cl}^{-}$released during GABA is strongly delayed. (B) illustrates a long-lasting application of furosemide. Under these circumstances a complete blockade of $\mathrm{Cl}^{-}$-reuptake occurred. Calibrations of the $\mathrm{Cl}_{\mathrm{i}}$-traces are given in free ion concentrations $\left(\mathrm{Cl}_{\mathrm{i}}\right)$ and in voltage of the ion signal $\left(\mathrm{V}_{\mathrm{Cl}}\right)$. $\mathrm{E}_{\mathrm{m}}$, membrane potential. 
The post-carbachol and post-ouabain membrane hyperpolarizations are consistent with an electrogenic transport ratio of the $\mathrm{Na}^{+} / \mathrm{K}^{+}$-pump. ${ }^{31}$

The ion movements observed in the presence of GABA are due to the opening of receptor-activated $\mathrm{Cl}^{--}$-channels. Measurements of the $\mathrm{Cl}^{-}$-equilibrium potential in rat sympathetic ganglia and other peripheral neurons have indicated that the free intracellular $\mathrm{Cl}$-concentration should be higher than expected from a passive distribution of this ion. ${ }^{1.16}$ This assumption could be confirmed by the direct ion recordings performed in the present study. The consequence of an increase in $\mathrm{Cl}^{-}$-conductance is therefore a $\mathrm{Cl}^{-}$-efflux according to the outwardly directed driving force. Parallel to a decrease of $\left[\mathrm{Cl}^{-}\right]_{i}$, a diminution of $\left[\mathrm{K}^{+}\right]_{i}$ and an increase of $\left[\mathrm{K}^{+}\right]_{e}$ were measured in the presence of GABA. A GABAinduced elevation of $\left[\mathrm{K}^{+}\right]_{e}$ has been previously observed in rat sympathetic ganglia, ${ }^{15}$ the frog spinal cord, ${ }^{21.29}$ rat dorsal root ganglia ${ }^{12}$ and rat pituitary. ${ }^{22}$ $\gamma$-Aminobutyric acid could induce a neuronal $\mathrm{K}^{+}$-efflux by activation of a receptor-coupled $\mathrm{K}^{+}$-channel, voltage-dependent $\mathrm{K}^{+}$-channels gated by the membrane depolarization and/or by an enhanced $\mathrm{K}^{+}$-flux via leak channels due to an increase of outwardly directed driving force. Whereas the first possibility seems to be unlikely in view of the equilibrium potential of the GABA depolarization, ${ }^{1,16}$ our data cannot distinguish between the two other alternatives. Our results clearly exclude a contribution of large changes of $\mathrm{Na}^{+}$-conductance to the GABA action, since no increases of $\left[\mathrm{Na}^{+}\right]_{i}$ were observed. However, a coupled $\mathrm{KCl}$-movement of the magnitude observed might be accompanicd by osmotic cffects. Thus, loss of $\mathrm{KCl}$ during GABA action could cause some cell shrinkage. This means that there might be a loss of $\mathrm{Na}^{+}$even though $\left[\mathrm{Na}^{+}\right]_{i}$ has not changed. At the moment, we cannot exclude this possibility.

The mechanism responsible for the reuptake of $\mathrm{K}^{+}$ released by the action of GABA seems to be different from the $\mathrm{Na}^{+} / \mathrm{K}^{+}$-pump. This view is supported by several observations: (a) $\gamma$-Aminobutyric acid did not increase $\left[\mathrm{Na}^{+}\right]_{i}$ and consequently cannot activate the $\mathrm{Na}^{+} / \mathrm{K}^{+}$-pump via its intracellular binding site. (b) No post-GABA $\left[\mathrm{K}^{+}\right]_{\mathrm{e}}$-undershoot (which is a typical indicator for the activation of an electrogenic $\mathrm{Na}^{+} / \mathrm{K}^{+}$-transport) was detectable. (c) Ouabain did not change the kinetics of the $\left[\mathrm{K}^{+}\right]_{\mathrm{e}}$ recovery period after the end of the GABA application, whereas a complete block of the post-carbachol $\left[\mathrm{K}^{+}\right]_{\mathrm{e}}$-undershoot occurred. These facts indicate that a $\mathrm{K}^{+}$-transport system different from the $\mathrm{Na}^{+} / \mathrm{K}^{+}$-pump might be involved. It is more likely that a $\mathrm{K}^{+} / \mathrm{Cl}^{-}$. cotransport may have such a function in the reuptake of $\mathrm{K}^{+}$released by GABA, because such a transport would restore both ions involved. Our data with furosemide support such a view. Furosemide is known to block a $\mathrm{Cl}^{-}$-dependent $\mathrm{K}^{+}$-influx in a variety of cells. ${ }^{3,13,14,18,20,26}$ Such a system seems to operate also in neurons of rat superior cervical ganglia. However, two aspects of a furosemidesensitive, $\mathrm{Cl}^{-}$-dependent $\mathrm{K}^{+}$-influx found in other cells have to be investigated in future experiments. These concern the source of energy required to drive the uphill transport of $\mathrm{K}^{\prime}$ and $\mathrm{Cl}^{-}$(participation of $\mathrm{Na}^{+}$-gradient?) and the consequences of such a transport system for the cell volume. Furthermore, we cannot exclude that furosemide, in addition to its effect on the ion transport, blocks the GABAreceptor associated $\mathrm{Cl}^{--}$-channel. Such an effect has been described on frog dorsal root terminals ${ }^{25}$ and cat dorsal root ganglia. ${ }^{17}$

Acknowledgements - We are grateful to Prof. Simon and Dr. Ammann, ETH Zürich for the gift of the $\mathrm{Na}^{+}$-sensitive ligand. We thank Ms. G. Schneider and Ms. I. Englmaier for the preparation of the ion-sensitive microelectrodes and Mrs. C. Müller for expert technical assistance. The work was supported by the Wilhelm Sander Stiftung.

\section{REFERENCES}

1. Adams P. R. and Brown D. A. (1975) Actions of $\gamma$-aminobutyric acid on sympathetic ganglion cells. J. Physiol., Lond. 250, 85-120.

2. Adams P. R., Brown D. A. and Constanti A. (1982) M-currents and other potassium currents in bullfrog sympathetic neurones. J. Physiol., Lond. 330, 537-572.

3. Aiton J. F., Chipperfield A. R., Lamb J. F., Ogden P. and Simmons N. L. (1981) Occurrence of passive furosemide-sensitive transmembrane potassium transport in cultured cells. Biochim. biophys. Acta 646, 389-398.

4. Ballanyi K., Grafe P. and ten Bruggencate G. (1983) Intracellular free sodium and potassium, post-carbachol hyperpolarization and extracellular potassium-undershoot in rat sympathetic neurones. Neurosci. Lett. 38, $275-279$.

5. Brown D. A. and Scholfield C. N. (1974) Changes of intracellular sodium and potassium ion concentrations in isolated rat superior cervical ganglia induced by depolarizing agents. J. Physiol., Lond. 242, 307-319.

6. Brown D. A. and Scholfield C. N. (1974) Movements of labelled sodium ions in isolated rat superior cervical ganglia. J. Physiol., Lond. 242, 321-351.

7. Brown D. A., Brownstein M. J. and Scholfield C. N. (1972) Origin of the after-hyperpolarization that follows removal of depolarizing agents from the isolated superior cervical ganglion of the rat. Br. J. Pharmac. 44, 651-671.

8. Brown K. T. and Flaming D. G. (1977) New microelectrode techniques for intracellular work in small cells. Neuroscience 2, 813-827.

9. Deisz R. A. and Lux H. D. (1982) The role of intracellular chloride in hyperpolarizing post-synaptic inhibition of crayfish stretch receptor neurones. J. Physiol., Lond. 326, 123-138.

10. Deitmer J. W. and Schlue W. R. (1981) Measurements of the intracellular potassium activity of Retzius cells in the leech central nervous system. J. exp. Biol. 91, 87-101.

11. Deitmer J. W. and Schlue W. R. (1983) Intracellular $\mathrm{Na}^{+}$and $\mathrm{Ca}^{2+}$ in leech Retzius neurones during inhibition of the $\mathrm{Na}^{+}-\mathrm{K}^{+}$-pump. Pfügers Arch. ges. Physiol. 397, 195-201. 
12. Deschenes M. and Feltz P. (1976) GABA-induced rise of extracellular potassium in rat dorsal root ganglia: an electrophysiological study in vivo. Brain Res. 118, 494-499.

13. Duhm J. and Göbel B. O. (1984) Role of the furosemide-sensitive $\mathrm{Na}^{+}-\mathrm{K}^{+}$transport system in determining the steady-state $\mathrm{Na}^{+}$and $\mathrm{K}^{+}$content and volume of human erythrocytes in vitro and in vivo. J. Membr. Biol. 77, $243-255$.

14. Dunham P. B., Steward G. W. and Ellory J. C. (1980) Cloride-activated passive potassium transport in human erythrocytes. Proc. natn Acad. Sci. U.S.A. 77, 1711-1715.

15. Förstl J., Galvan M. and ten Bruggencate G. (1982) Extracellular $\mathbf{K}^{+}$-concentration during electrical stimulation of rat isolated sympathetic ganglia, vagus and optic nerves. Neuroscience 7, 3221-3229.

16. Gallagher J. P., Higashi H. and Nishi S. (1978) Characterization and ionic basis of GABA-induced depolarizations recorded in vitro from cat primary afferent neurones. J. Physiol., Lond. 275, 263-282.

17. Gallagher J. P., Nakamura J. and Shinnick-Gallagher P. (1983) The effects of temperature, pH and Cl-pump inhibitors on GABA responses recorded from cat dorsal root ganglia. Brain Res. 267, 249-259.

18. Geck P., Pietrzyk C., Burckhardt B. C., Pfeiffer B. and Heinz E. (1980) Electrically silent cotransport of $\mathrm{Na}^{+}, \mathrm{K}^{+}$and $\mathrm{Cl}^{-}$in Ehrlich cells. Biochim. biophys. Acta 600, 432-447.

19. Grafe P., Rimpel J., Reddy M. M. and ten Bruggencate G. (1982) Changes of intracellular sodium and potassium ion concentrations in frog spinal motoneurones induced by repetitive synaptic stimulation. Neuroscience 7, 3213-3220.

20. Greger R., Schlatter E. and Lang F. (1983) Evidence for electroneutral sodium chloride cotransport in the cortical thick ascending limb of Henle's loop of rabbit kidney. Pfiügers Arch. ges. Physiol. 396, 308-314.

21. Kudo Y. and Fukuda H. (1976) Alteration of extracellular $\mathbf{K}^{+}$-activity induced by amino acids in the frog spinal cord. Jap. J. Pharmac. 26, 385-387.

22. Loeffler J. Ph., Desaulles E., Demeneix B. A. and Feltz P. (1982) Electrophysiological study with $\mathrm{K}^{+}$- and $\mathrm{Ca}^{2+}$-sensitive micropipettes of GABA receptors in the rat neurointermediate lobe in vitro. Neurosci. Lett. 34, 271-276.

23. Narahashi T. (1974) Chemicals as tools in the study of excitable membranes. Physiol. Rev. 54, 813-889.

24. Nicholson C. (1981) Brain-cell microenvironment as a communication channel. In The Neurosciences-Fourth Study Program (ed. Schmidt F. O. and Worden F.), pp. 457-476. MIT-Press, Cambridge, U.S.A.

25. Nicoll R. A. (1978) The blockade of GABA mediated responses in frog spinal cord by ammonium ions and furosemide. J. Physiol., Lond. 283, 121-132.

26. Russell J. M. (1983) Cation-coupled chloride influx in squid axon. Role of potassium and stoichiometry of the transport process. J. gen. Physiol. 81, 909-925.

27. Scholfield C. N. (1977) Movements of radioactive potassium in isolated rat ganglia. J. Physiol., Lond. 268, $123-137$.

28. Somjen G. G. (1979) Extracellular potassium in the mammalian central nervous system. A. Rev. Physiol. 41, $159-177$.

29. Syková E. (1979) GABA-induced changes of extracellular $\mathrm{K}^{+}$-activity in the frog spinal cord. Physiologia bohemoslov. 27, 189-192.

30. Thomas R. C. (1972) Intracellular sodium activity and the sodium pump in snail neurones. J. Physiol, Lond. $220,55-71$.

31. Thomas R. C. (1972) Electrogenic sodium pump in nerve and muscle cells. Physiol. Rev. 52, 563-594.

32. Vaughan-Jones R. D. (1979) Non-passive chloride distribution in mammalian heart muscle: micro-electrode measurement of the intracellular chloride activity. J. Physiol., Lond. 295, 83-109.

33. Yoshikami D. (1981) Transmitter sensitivity of neurons assayed by autoradiography. Science, N.Y. 212, 929-930. 